\title{
Determinants of serum 25-hydroxyvitamin D in Hong Kong
}

\author{
Cuiling $\mathrm{Xu}^{1}$, Ranawaka A. P. M. Perera ${ }^{1}$, Yap-Hang Chan ${ }^{1,2}$, Vicky J. Fang ${ }^{1}$, Sophia $\mathrm{Ng}^{3}$, Dennis K. \\ M. Ip ${ }^{1}$, Andrea May-Sin Kam ${ }^{1}$, Gabriel M. Leung ${ }^{1}$, J. S. Malik Peiris ${ }^{1}$ and Benjamin J. Cowling ${ }^{1 *}$ \\ ${ }^{1}$ School of Public Health, Li Ka Shing Faculty of Medicine, The University of Hong Kong, 21 Sassoon Road, Pokfulam, \\ Hong Kong \\ ${ }^{2}$ Division of Cardiology, Department of Medicine, Queen Mary Hospital, The University of Hong Kong, Hong Kong \\ ${ }^{3}$ School of Public Health, University of Michigan, Ann Arbor, MI, USA
}

(Submitted 14 April 2014 - Final revision received 23 March 2015 - Accepted 15 April 2015 - First published online 8 June 2015)

\begin{abstract}
Vitamin D plays an important role in skeletal health throughout life. Some studies have hypothesised that vitamin D may reduce the risk of other diseases. Our study aimed to estimate age-specific and sex-specific serum 25-hydroxyvitamin D (25(OH)D) status and to identify the determinants of serum 25(OH)D status in Hong Kong, a subtropical city in southern China. In 2009-2010, households in Hong Kong were followed up to identify acute respiratory illnesses, and sera from 2694 subjects were collected in three to four different study phases to permit measurement of $25(\mathrm{OH}) \mathrm{D}$ levels at different times of the year. A questionnaire survey on diet and lifestyle was conducted among children, with simultaneous serum collection in April and May 2010. The mean of serum 25(OH)D levels in age groups ranged from 39 to $63 \mathrm{nmol} / \mathrm{l}$ throughout the year with the mean values in all age groups in spring below $50 \mathrm{nmol} / \mathrm{l}$. Children aged $6-17$ years, and girls and women had significantly lower serum 25(OH)D levels than adults, and boys and men, respectively (all $P<0 \cdot 001$ ). We estimated that serum 25(OH)D levels in Hong Kong followed a lagged pattern relative to climatic season by 5 weeks with lowest observed levels in early spring (March). For children aged 6-17 years, reporting a suntan, having at least 1 servings of fish/week and having at least 1 serving of eggs/week were independently associated with higher serum 25(OH)D levels. Adequate sunlight exposure and increased intake of dietary vitamin D could improve vitamin D status, especially for children and females in the winter and spring.
\end{abstract}

\section{Key words: Vitamin D: 25-Hydroxyvitamin D: Age: Solar radiation: Hong Kong}

Vitamin D plays an important role in skeletal health, and vitamin $\mathrm{D}$ deficiency is known to be a cause of rickets and osteoporosis $^{(1)}$. In addition, a wide range of tissues and cells have been found to possess vitamin D receptors. Observational studies have suggested that low 25-hydroxyvitamin D $(25(\mathrm{OH}) \mathrm{D})$ values are associated with an increased risk for several non-skeletal diseases, including cancer ${ }^{(2,3)}$, infectious diseases $^{(4-7)}$ and CVD $^{(8)}$. Vitamin D inadequacy is being increasingly recognised worldwide, and remains common in children and adults ${ }^{(1,9,10)}$.

Human subjects acquire vitamin D from exposure to sunlight, from their diet and from dietary supplements ${ }^{(1)}$. The main natural source of vitamin D is the sun, as vitamin D is synthesised in the skin after exposure to solar UV B radiation (wavelength $290-315 \mathrm{~nm})^{(1)}$. A diet high in oily fish prevents vitamin D deficiency $^{(11)}$. Vitamin D from the skin and diet converts to $25(\mathrm{OH}) \mathrm{D}$ in the liver and subsequently to 1,25 dihydroxyvitamin $\mathrm{D}\left(1,25(\mathrm{OH})_{2} \mathrm{D}\right)$ in the kidney, which is the active form of vitamin $\mathrm{D}^{(1)} \cdot 25(\mathrm{OH}) \mathrm{D}$ is the principal form of vitamin $\mathrm{D}$ that circulates in the blood stream and can be used as a marker to determine vitamin D status ${ }^{(12)}$.

Hong Kong is a subtropical coastal city in southern China, with sufficient sunshine during the whole year and fish is commonly consumed in the local diet. However, there are few data on vitamin D status by age and sex in residents, and on the effect of dietary and sun exposures on vitamin D status in Hong Kong. Seasonal variation in vitamin D status is thought to play a role in the seasonality of bone mass ${ }^{(13,14)}$. However, there is a paucity of data on the seasonality of vitamin D levels in subtropical Hong Kong, where there is relatively little variation in the hours of sunlight throughout the year.

We conducted a household-based prospective study from September 2009 through December 2010 in Hong Kong ${ }^{(15)}$. The study was primarily designed to study the direct and indirect effectiveness of influenza vaccination among school-age children in preventing influenza virus infections in their households. For the present study, we determined vitamin D

Abbreviation: 25(OH)D, 25-hydroxyvitamin D.

*Corresponding author: Dr B. J. Cowling, fax +852 3520 1945, email bcowling@hku.hk 
status in stored sera to describe the seasonal variation in vitamin $\mathrm{D}$ status in children and adults over time, and to investigate the determinants of vitamin D status. Our present study also included an additional questionnaire survey conducted among participating children 6-17 years of age in April and May 2010 to collect information on sun-seeking behaviors, and dietary and supplementary habits that might affect vitamin D status.

\section{Methods}

\section{Study participants}

Participants included in this study of vitamin D were part of a household-based prospective study of influenza, as describe elsewhere $^{(15)}$. In 2009-2010, we recruited all members of 796 households, and each household included a child 6-17 years of age who was randomly allocated to receive either a single dose of seasonal trivalent inactivated influenza vaccine or placebo in a double-blind manner. Enrollment, collection of serum specimens and vaccinations were performed by trained research staff at a study clinic. Serum specimens were collected at baseline (September 2009 through February 2010) and after 12 months at the end of the follow-up period ('post-study', October through December 2010). Serum specimens were also collected 1 month after vaccination from the children who received vaccine or placebo ('post-vaccination', October 2009 through February 2010). A subset of participants also provided blood samples half-way through the study ('mid-study', April and May 2010).

Using a vitamin D questionnaire designed according to previous studies in the United States ${ }^{(16,17)}$, we collected data about sun-seeking behaviors, and dietary and vitamin D supplementary habits from these children aged 6-17 years who also provided mid-study serum specimens in April and May 2010. The questionnaires were completed by the children together with their parents.

\section{Ethics}

Written consent was obtained from all adult subjects. Proxy written consent from parents or legal guardians was obtained for participants 17 years of age and younger, with additional written assent from those aged 8-17 years. The study protocol was approved by the Institutional Review Board of The University of Hong Kong.

\section{Laboratory analysis}

Blood from all household members were collected in tubes containing clot activator and held at $4-8^{\circ} \mathrm{C}$ from collection until receipt at the laboratory. At the laboratory, each specimen was centrifuged to extract the sera, which was then frozen at $-80^{\circ} \mathrm{C}$. The serum specimens were subsequently tested for $25(\mathrm{OH}) \mathrm{D}$ using the OCTEIA ELISA 25-Hydroxyvitamin D Immunoassay Kit manufactured by Immunodiagnostic Systems Limited $^{(18)}$. According to the package insert of the assay, the inter-assay $\mathrm{CV}$ for the $25(\mathrm{OH}) \mathrm{D}$ assay was $4.6-8.7 \%$, and the intra-assay $\mathrm{CV}$ was $5 \cdot 3-6.7 \%$. In our own laboratory, we found that the intra-assay CV was $7 \cdot 4 \%$.

\section{Statistical analysis}

We anticipated that we would have at least $80 \%$ power to detect at least a $9 \mathrm{nmol} / \mathrm{l}$ difference in serum 25(OH)D between any two groups (four age groups and male/female) in each season, assuming a standard deviation of 15-18 nmol/l based on data available for mean and standard deviation of serum $25(\mathrm{OH}) \mathrm{D}$ by sex in a normal population from the literature ${ }^{(19)}$. The sample size of sixty-three in each age or sex group would be adequate to test the difference in the mean of serum $25(\mathrm{OH}) \mathrm{D}$ by age or sex in a single season. We anticipated that the present overall study sample size of 2694 individuals with repeated measurements would permit reliable comparisons between seasons, by age and sex, and would allow us to identify moderate effects of determinants after accounting for serial correlation in the measurements.

The participants were categorised into four age groups, i.e. $6-17,18-44,45-64$ and $\geq 65$ years. The four seasons were defined as spring (March-May), summer (June-August), autumn (September-November), and winter (DecemberFebruary), respectively. The 25(OH)D levels were categorised into different seasons based on the data of specimen collection. If two specimens from the same subject were categorised to the same season, we used the average $25(\mathrm{OH}) \mathrm{D}$ level of the two specimens. Since no blood specimens were collected in the study during June to August, no data on 25(OH)D levels in the summer of 2010 were available.

We used a generalised linear model to compare the mean of serum $25(\mathrm{OH})$ by age and sex in each season to estimate agespecific and sex-specific patterns in serum 25(OH)D levels. Since solar radiation can reflect climatic season, we fitted a random-effects linear regression model to obtain quantitative seasonality estimates of serum $25(\mathrm{OH}) \mathrm{D}$ based on the repeated measures of serum $25(\mathrm{OH}) \mathrm{D}$, which included daily level of solar radiation as a predictive factor. Daily means of solar radiation were obtained from Hong Kong observatory, and were smoothed using Kernel density smoothing as a proxy measure for seasonal variation in the climate in Hong Kong ${ }^{(20)}$. In a separate secondary analysis, a random-effects sinusoidal linear regression model with annual periodicity was fitted to characterise the seasonal variation of serum $25(\mathrm{OH}) \mathrm{D}$. In the two random-effects linear regression models used to estimate the seasonal variation of serum $25(\mathrm{OH}) \mathrm{D}$, the associations of $25(\mathrm{OH}) \mathrm{D}$ with age, sex, educational attainment of the household head, vaccination and chronic conditions were adjusted for. The ratio of serum $25(\mathrm{OH}) \mathrm{D}$ levels between the peak season and the trough season in each age group was calculated to estimate the degree of seasonal variation in serum 25(OH)D levels.

Since both vitamin D questionnaires and mid-study sera were collected simultaneously from a subset of participating children aged 6-17 years in April to May 2010, we performed univariable and multivariable analyses to explore the determinants of serum vitamin D levels among children 
using generalised linear models. A multiple linear model with backward selection was used to exclude variables one by one from an initially complete model. Only the factors with $P$-values $<0.2$ were included in the final model. Statistical analyses were conducted in $\mathrm{R}$ version 2.15.1 ( $\mathrm{R}$ Foundation for Statistical Computing) and SAS version 9.2 (SAS Institute).

\section{Results}

\section{Characteristics of participants}

In total, 3030 people participated in the previous influenza household study, and fifty-three people from fourteen households withdrew or were lost to follow-up. From 3030 participants, 2694 (89\%) had at least one serum specimen available for $25(\mathrm{OH}) \mathrm{D}$ testing (Table 1 ). Of the 2694 participants, 2459 (91\%) and 1341 (50\%) had two or more and three or more serum specimens available for $25(\mathrm{OH}) \mathrm{D}$ testing, respectively (Fig. 1). There was no difference in age, sex, educational attainment of household head, vaccination history and chronic conditions between 3030 participants in the influenza household study and 2694 participants included in the vitamin D analysis (Table 1). The median age of these 2694 participants was 33 years (interquartile range $11-43$ years), and $46 \%$ were male. Of these 2694 participants, $21 \%$ reported receipt of 2009-2010 seasonal influenza vaccine, and 16\% had a self-reported chronic condition.

\section{Mean of serum 25-hydroxyvitamin D by age and} sex in different seasons

Table 2 presents the comparative analysis of serum 25(OH)D levels in each season by age and sex. In each season, children aged 6-17 years had significantly lower vitamin D levels

Table 1. Demographic characteristics of participants in this study (Number of participants and percentages)

\begin{tabular}{|c|c|c|c|}
\hline \multirow[b]{2}{*}{ Characteristic } & \multicolumn{2}{|c|}{$\begin{array}{c}\text { Subjects with } \geq 1 \text { blood } \\
\text { sample tested for vitamin D } \\
\text { level }(n \text { 2694) }\end{array}$} & \multirow[b]{2}{*}{$P$} \\
\hline & $n$ & $\%$ & \\
\hline Age group (years) & & & 0.11 \\
\hline $0-5$ & 0 & 0 & \\
\hline $6-17$ & 1165 & 43 & \\
\hline $18-44$ & 933 & 35 & \\
\hline $45-64$ & 544 & 20 & \\
\hline $65+$ & 51 & 2 & \\
\hline Sex & & & 0.99 \\
\hline Men & 1251 & 46 & \\
\hline $\begin{array}{l}\text { Educational attainment } \\
\text { of household head }\end{array}$ & & & 0.98 \\
\hline Primary or below & 205 & 8 & \\
\hline Secondary & 1842 & 68 & \\
\hline Tertiary & 647 & 24 & \\
\hline $\begin{array}{l}\text { Receipt of } 2009-2010 \\
\text { seasonal influenza vaccine }\end{array}$ & & & 0.91 \\
\hline No & 2136 & 79 & \\
\hline Yes & 557 & 21 & \\
\hline Any chronic condition & & & 0.96 \\
\hline No & 2264 & 84 & \\
\hline Yes & 429 & 16 & \\
\hline
\end{tabular}

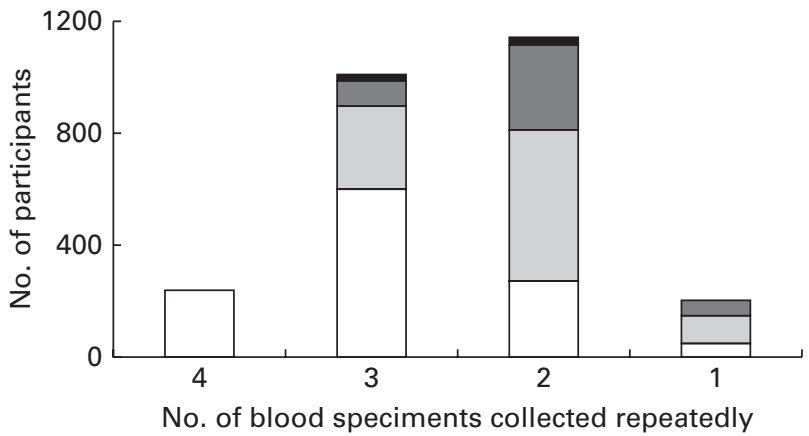

Fig. 1. The number of serum specimens collected repeatedly in four age groups (6-17 years $(\square), 18-44$ years $(\square), 45-64$ years $(\square)$ and $\geq 65$ years $(\square)$ ).

$(39-53 \mathrm{nmol} / \mathrm{l})$ compared to adults aged $18-44$ years $(42-57$ nmol/1) (all $P<0 \cdot 001)$. Adults aged $45-64$ years $(47-63 \mathrm{nmol} / \mathrm{l})$ had significantly higher serum $25(\mathrm{OH}) \mathrm{D}$ levels than adults aged 18-44 years in the other three seasons (all $P<0 \cdot 01$ ) except in the winter of 2009-2010.The mean serum 25(OH)D level in adults aged 65 years or older $(41-56 \mathrm{nmol} / \mathrm{l})$ was not significantly different from adults aged 18-44 years in each season. Males had significantly higher serum 25(OH)D levels (3-5 nmol/1) than females in each season.

\section{Seasonal variation of serum 25-hydroxyvitamin D}

The pattern of daily solar radiation showed one peak (August) in Hong Kong (Fig. 2). Using the random-effects linear regression model, we found that the daily level of solar radiation, age and sex were significantly associated with serum 25(OH)D levels after adjusting for other factors (online Supplementary Table S1). For males and females in the age groups of $6-17,18-44,45-64$ years, the model that included a 5 -week lag in solar radiation gave the best fit to time-varying serum 25(OH)D levels (all $P<0.05$ ) (Fig. 3(a)-(c)). We identified significant seasonal fluctuation in serum $25(\mathrm{OH}) \mathrm{D}$ levels for males and females in the age groups of 6-17, 18-44 and 45-64 years, which peaked in September (autumn), and dropped to lowest levels in March (Spring). As much as $10.6 \%$ of the variation in vitamin D levels was explained by the inclusion of seasonal variation in solar radiation in the model. In all four age groups, the average of predicted serum 25(OH)D levels in boys/men was $4-9 \mathrm{nmol} / \mathrm{l}$ higher than in girls/women (all $P<0 \cdot 05$ ). In a secondary analysis using the random-effects sinusoidal linear regression model, we found that there was a similar degree of seasonal fluctuation in serum $25(\mathrm{OH}) \mathrm{D}$ levels for different age and sex groups to the first random-effects model, while the first random-effects model incorporating solar radiation better explained the seasonal variation in serum 25(OH)D levels. The ratio of serum $25(\mathrm{OH}) \mathrm{D}$ levels between the spring and the autumn of 2010 in each age group varied from 1.3 to 1.4 .

\section{Factors that influence serum 25-hydroxyvitamin D among children}

A total of 321 children completed vitamin D questionnaires and also provided mid-study serum specimens in April and 
May 2010. The median age of participants in the questionnaire survey was 11 years (interquantile range 9-12 years). As much as $86 \%$ of participants reported a suntan in the past year, and $20 \%$ reported an average of at least $1 \mathrm{~h}$ of sun exposure/d in the past week; 21, 30 and $38 \%$ of participants reported having an average of at least 1 daily serving of fish, milk and eggs, respectively; 9, 6 and $60 \%$ reported the use of additional vitamin D supplements, intake of multivitamins, and use of cod liver or fish oil, respectively.

In univariable analyses, younger age, male sex, reporting a suntan, having at least 1 serving of fish/week, having at least 1 serving of $\mathrm{milk} / \mathrm{d}$, and taking cod liver oil or fish oil were significantly associated with higher serum 25(OH)D levels (Table 3). In multivariable analysis, younger age, male sex, reporting a suntan, having at least 1 serving of fish/week and having at least 1 serving of eggs/week were independently associated with higher serum 25(OH)D levels (Table 3).

\section{Discussion}

In the present study, we characterised seasonal fluctuations in serum $25(\mathrm{OH}) \mathrm{D}$ levels in subtropical Hong Kong at $22^{\circ}$ latitude, identifying peaks in September and troughs in March, following a lagged pattern relative to climatic seasons. We found that the mean of serum $25(\mathrm{OH}) \mathrm{D}$ levels in the peak season for each age group was 1.3 to 1.4 times higher than that in the trough season, while the peak:trough ratios tend to be slightly greater in temperate locations such as the Netherlands ${ }^{(21)}$, Germany ${ }^{(22)}$, Italy ${ }^{(23)}$ and Japan ${ }^{(19)}$. In spring, the means of serum $25(\mathrm{OH}) \mathrm{D}$ in each of four age groups were below $50 \mathrm{nmol} / 1$ that is recommended by the Institute of Medicine $\mathrm{RDA}^{(24)}$, and in the other seasons, these values were below the requirements recommended by the International Osteoporosis Foundation and the US Endocrine Society $(\geq 75 \mathrm{nmol} / \mathrm{l})^{(25)}$. In Hong Kong, the means of serum $25(\mathrm{OH}) \mathrm{D}$ in different age groups were also lower than those

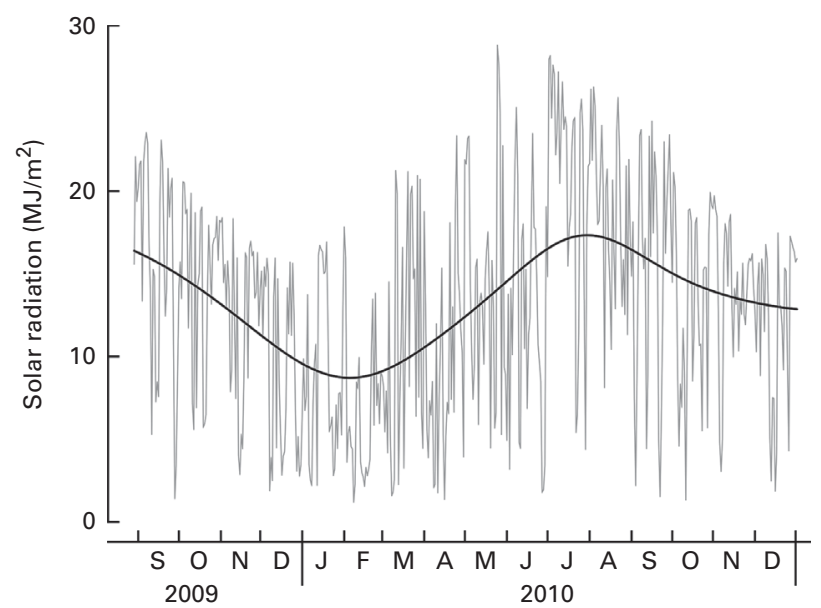

Fig. 2. Daily levels of solar radiation $\left(\mathrm{MJ} / \mathrm{m}^{2}\right)$ that were obtained based on daily means of solar radiation from Hong Kong observatory using Kernel density smoothing as a proxy measure for meteorological season (— daily means of solar radiation, - , daily level of solar radiation). J, January; F, February; M, March; A, April; M, May; J, June, J, July; A, August; S, September; O, October; N, November; D, December. 

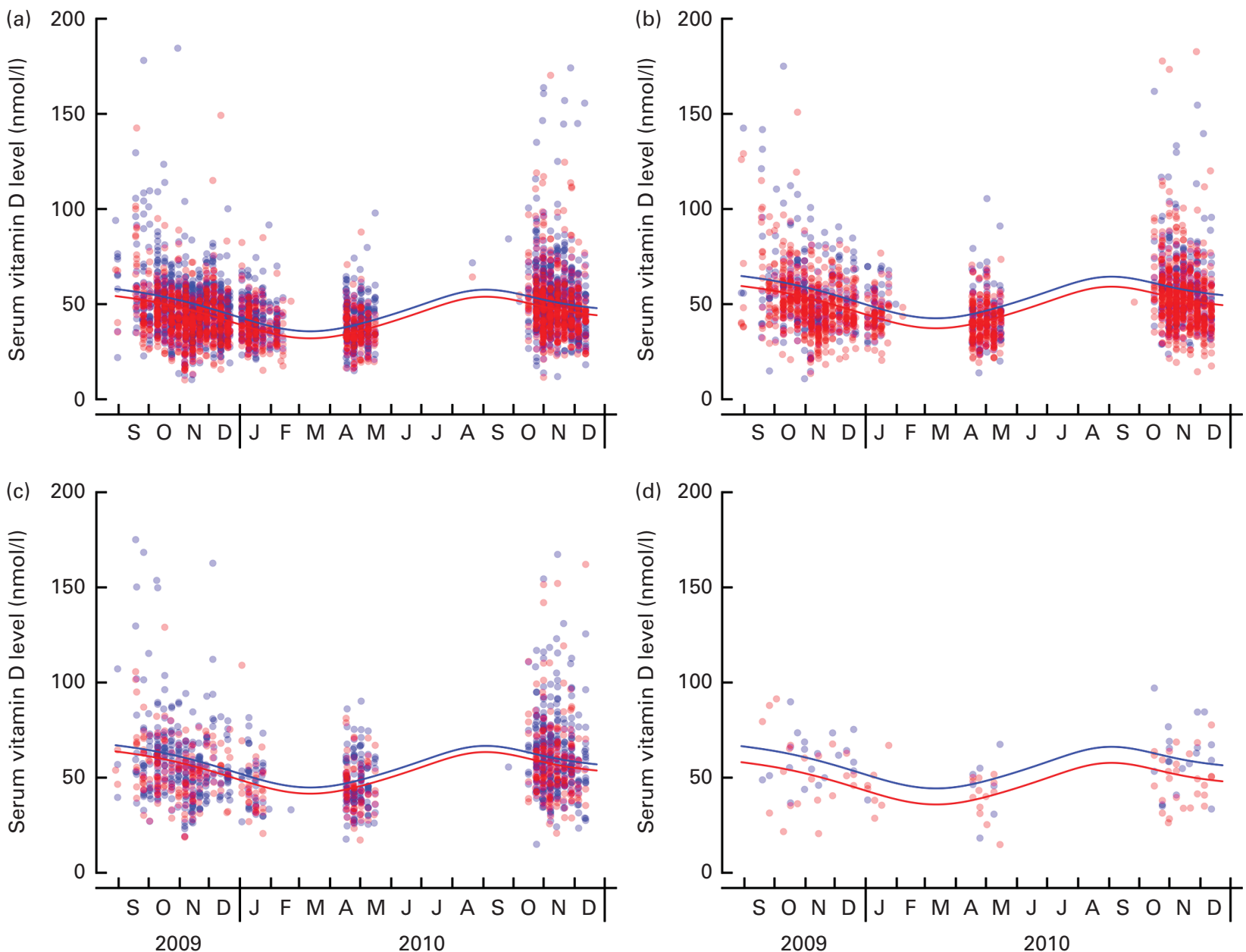

Fig. 3. Serum 25-hydroxyvitamin $\mathrm{D}(25(\mathrm{OH}) \mathrm{D})$ levels $(\mathrm{nmol} / \mathrm{l})$ from each individual and a random-effects linear regression model of serum $25(\mathrm{OH}) \mathrm{D}$ level fitted to daily level of solar radiation as a covariate, adjusting for age groups and sex. The vitamin D levels in subjects (a) 6-17 years, (b) 18-44 years, (c) 45-64 years and $(d) \geq 65$ years, and - in each figure indicate the mean levels of serum vitamin $D$ for men and women in the fitted model ( $\bullet-$, male and $-\bullet$, female). J, January; F, February; M, March; A, April; M, May; J, June, J, July; A, August; S, September; O, October; N, November; D, December.

reports at the similar age groups from Japan, Thailand and Vietnam in Asia and most reports from the countries in North America ${ }^{(10,26-31)}$. Moreover, the means of serum $25(\mathrm{OH}) \mathrm{D}$ the present study reported were lower than that $(77 \mathrm{nmol} / \mathrm{l})$ in Taiwan where the latitude $\left(25^{\circ}\right)$ is similar to Hong Kong ${ }^{(32)}$. The reasons why living in Hong Kong with lower latitudes does not appear to protect against vitamin D insufficiency is likely due to several factors, potentially including less time spent outdoors, less vitamin $\mathrm{D}$ intake from diet or dietary supplements, skin pigmentation of the local Chinese residents $^{(11)}$, air pollution ${ }^{(33)}$ or other racial differences in genetic polymorphism ${ }^{(34)}$.

Similar to the findings from several temperate locations ${ }^{(19,35-40)}$, the present study estimated that there is substantial seasonal fluctuation in serum $25(\mathrm{OH}) \mathrm{D}$ levels in Hong Kong. Previous studies in subtropical Taiwan, Florida and Hong Kong reported the differences in serum 25(OH)D level between summer (or autumn) and winter ${ }^{(32,41,42)}$. However, the present study of 15-month study duration was able to predict the year-round seasonal fluctuation by using a cyclic regression model, although there was a lack of data on summer levels of serum $25(\mathrm{OH}) \mathrm{D}$ in the present study. Sun exposure and solar radiation are known to be a major determinant of vitamin D status ${ }^{(1)}$ and the seasonal pattern of vitamin $\mathrm{D}$ in Hong Kong is consistent with seasonal variation in solar radiation. In Hong Kong, hours of sunlight (136 and $111 \mathrm{~h} /$ month, respectively) and solar radiation $\left(10\right.$ and $12 \mathrm{MJ} / \mathrm{m}^{2}$, respectively) in winter and spring are lower than those (182 and $182 \mathrm{~h} /$ month; 16 and $14 \mathrm{MJ} / \mathrm{m}^{2}$ respectively) in summer and autumn ${ }^{(20)}$. The weather in winter and spring is suitable for outdoor activity in Hong Kong, while in the autumn temperatures are still high $\left(22-27^{\circ} \mathrm{C}\right)$, so people also reduce outdoor activity during daytime. A previous study in Hong Kong in the 1980s reported that the means of serum $25(\mathrm{OH}) \mathrm{D}$ levels in young healthy people were 26.8 and $23.4 \mu \mathrm{g} / 1$ (equal to 67.0 and $58.5 \mathrm{nmol} / \mathrm{l})$ in September and January, respectively ${ }^{(41)}$, which were higher than the means in the present study for the age group 18-44 years at similar months.

Some previous studies found that ageing is associated with the reduction of vitamin D synthesis; however, the association 
Table 3. The individual characteristics of sun-seeking behaviors, diet and vitamin D supplements, and their associations with serum 25-hydroxyvitamin $\mathrm{D}(\mathrm{nmol} / \mathrm{l})$ levels among children 6-17 years of age in Hong Kong, in April and May 2010

(Number of participants and percentages; adjusted $\beta$ coefficients and $95 \%$ confidence intervals)

\begin{tabular}{|c|c|c|c|c|c|c|c|c|}
\hline Characteristics & $n$ & $\%$ & Unadjusted $\beta$ & $95 \% \mathrm{Cl}$ & $P^{\star}$ & Unadjusted $\beta$ & $95 \% \mathrm{Cl}$ & $P^{\star}$ \\
\hline \multicolumn{9}{|l|}{ Age (years) } \\
\hline $6-8$ & 70 & 22 & Ref. & & & Ref. & & \\
\hline $9-11$ & 109 & 34 & $-4 \cdot 62$ & $-7 \cdot 90,-1 \cdot 35$ & $<0.01$ & -4.69 & $-8.04,-1.34$ & $<0.01$ \\
\hline $12-17$ & 142 & 44 & $-6 \cdot 76$ & $-9.88,-3.63$ & $<0.001$ & -3.96 & $-7 \cdot 11,0.81$ & $<0.05$ \\
\hline Sex & & & $<0.001$ & & $<0.01$ & & & \\
\hline Male & 171 & 53 & 3.803 & $1 \cdot 402,6 \cdot 204$ & & 3.92 & $1.48,6.36$ & \\
\hline Reporting suntan in the past year & 260 & 86 & $5 \cdot 31$ & $1 \cdot 75,8 \cdot 86$ & $<0.01$ & 4.06 & $0.57,7.55$ & $<0.015$ \\
\hline Sunscreen used & 124 & 39 & $2 \cdot 072$ & $-0.437,4.582$ & $0 \cdot 11$ & & & \\
\hline \multicolumn{9}{|l|}{ Sun exposure in the past week } \\
\hline$<1 \mathrm{~h} /$ week & 33 & 11 & Ref. & & & & & \\
\hline $1-6 \mathrm{~h} /$ week & 213 & 69 & 2.95 & $-1 \cdot 14,7 \cdot 03$ & $0 \cdot 16$ & & & \\
\hline$\geq 7 \mathrm{~h} /$ week & 61 & 20 & 1.00 & $-3 \cdot 72,5 \cdot 73$ & 0.68 & & & \\
\hline \multicolumn{9}{|l|}{ Meals of fish per week } \\
\hline$<1$ meal of fish/week & 10 & 3 & Ref. & & & Ref. & & \\
\hline $1-6$ meals of fish/week & 240 & 75 & 11.08 & $4 \cdot 07,18 \cdot 10$ & $<0.01$ & $11 \cdot 38$ & $4 \cdot 70,18 \cdot 06$ & $<0.001$ \\
\hline$\geq 7$ meals of fish/week & 68 & 21 & $12 \cdot 83$ & $5 \cdot 71,19 \cdot 95$ & $<0.001$ & $11 \cdot 78$ & $5 \cdot 00,18.55$ & $<0.001$ \\
\hline \multicolumn{9}{|l|}{ Cups of milk per week } \\
\hline$<1$ average cup of milk/week & 78 & 25 & Ref. & & & & & \\
\hline $1-6$ cups of milk/week & 139 & 45 & 3.02 & $-0.06,6 \cdot 10$ & 0.06 & & & \\
\hline$\geq 1$ cups of milk/d & 93 & 30 & 4.91 & $1.57,8 \cdot 26$ & $<0.01$ & & & \\
\hline \multicolumn{9}{|l|}{ Number of eggs per week } \\
\hline$<1$ egg/week & 10 & 3 & Ref. & & & Ref. & & \\
\hline $1-6$ eggs/d & 188 & 59 & $4 \cdot 26$ & $-2 \cdot 78,11 \cdot 31$ & 0.24 & $7 \cdot 26$ & $0.55,13.98$ & $<0.05$ \\
\hline$\geq 7$ eggs/week & 119 & 38 & 7.01 & $-0.38,14.41$ & 0.07 & 9.25 & $2 \cdot 11,16 \cdot 39$ & $<0.05$ \\
\hline Vitamin D supplement & 30 & 9 & 0.92 & $-3 \cdot 29,5 \cdot 13$ & 0.68 & & & \\
\hline Multivitamin & 20 & 6 & 1.95 & $-3.12,7.03$ & 0.45 & & & \\
\hline Intake cod liver oil or fish oil & 64 & 20 & 3.425 & $0.401,6.450$ & $<0.015$ & 2.99 & $-0 \cdot 12,6 \cdot 11$ & 0.06 \\
\hline \multicolumn{9}{|l|}{ Skin colour compared with classmates } \\
\hline Much darker & 9 & 3 & Ref. & & & Ref. & & \\
\hline Darker & 67 & 21 & -3.53 & $-11 \cdot 25,4 \cdot 20$ & 0.37 & $-1 \cdot 68$ & $-9 \cdot 06,5 \cdot 71$ & 0.66 \\
\hline Similar & 183 & 57 & 5.88 & $-13 \cdot 31,1.55$ & 0.12 & $-5 \cdot 32$ & $-12 \cdot 38,1 \cdot 74$ & 0.14 \\
\hline Lighter & 54 & 17 & $-6 \cdot 22$ & $-14.05,1.62$ & $0 \cdot 12$ & $-5 \cdot 54$ & $-12.98,1.90$ & 0.15 \\
\hline Much lighter & 7 & 2 & 3.56 & $-7 \cdot 40,14.53$ & 0.52 & $2 \cdot 67$ & $-7.59,12.94$ & 0.61 \\
\hline Diseases of digestive system & 2 & 1 & 1.08 & $-14 \cdot 46,16 \cdot 62$ & 0.89 & & & \\
\hline Diarrhoea in past 2 weeks & 18 & 6 & -0.30 & $-5 \cdot 63,5.02$ & 0.91 & & & \\
\hline
\end{tabular}

Ref., reference group.

${ }^{*}$ A multiple linear model with backward selection was used. Only the factors with $P$ values $<0.2$ were included in the final model.

of age with vitamin D status in children, young adults and middle-aged adults is inconsistent ${ }^{(19,43)}$. The present study found that for adults under 65 years and children aged 6-17 years, serum $25(\mathrm{OH}) \mathrm{D}$ levels increased with age. This could be explained by children having the capacity to produce $25(\mathrm{OH}) \mathrm{D}$ and $1,25(\mathrm{OH}) 2 \mathrm{D}$ due to healthy renal and liver function, whereas adults may produce less of these metabolites due to declining renal function and decreasing capacity of the skin to produce vitamin D precursors. As in Asian and Western countries, the present study also provided evidence that females had lower 25(OH)D levels than males $^{(19,42,44-46)}$. The sex difference in serum 25(OH)D status could be explained by men and boys having more sunlight exposure, and more usage of sunscreen by girls or women because of cosmetic concerns.

We identified five factors associated with higher serum 25(OH)D levels among children 6-17 years of age, namely younger age, male sex, reporting a suntan, having at least 1 serving of fish/week and having at least 1 serving of eggs/week. Only a limited number of foods naturally contain vitamin D. Oily fish and egg yolks are rich in both vitamin $\mathrm{D}_{3}$ and $25(\mathrm{OH}) \mathrm{D}_{3}$, which is consistent with more fish and egg ingestion helping to increase serum $25(\mathrm{OH}) \mathrm{D}_{3}$ levels ${ }^{(47,48)}$. A suntan reflects a large amount of cutaneous sun exposure, so children reporting a suntan had higher serum $25(\mathrm{OH}) \mathrm{D}$ level ${ }^{(17)}$. The higher serum 25(OH)D levels in children aged 6-8 years and boys might be related to more skin synthesis after sun exposure. However, reporting a suntan and the amount of hours of sun exposure in the recent week collected in the questionnaire could not reflect fully the duration of sun exposure in the longer period and the timing of sun exposure related to the zenith angle of the sun.

This present study has several limitations. First, seasonal variation in serum $25(\mathrm{OH}) \mathrm{D}$ was assessed using the data collected over 15 months with a lack of data on $25(\mathrm{OH}) \mathrm{D}$ in the summer months, and a longer time series of $25(\mathrm{OH}) \mathrm{D}$ levels would improve the determination of the seasonal variations of $25(\mathrm{OH}) \mathrm{D}$. Second, the present study had a limited sample size in elderly persons ( $\geq 65$ years) and this reduced the precision of estimates in that age group. Third, the factors associated with serum 25(OH)D level among children might not be the same for adults. Finally, we did not select partici- 
pants at random from the population of Hong Kong, and our estimates of $25(\mathrm{OH}) \mathrm{D}$ levels might need adjustment before being used to infer the mean of serum $25(\mathrm{OH}) \mathrm{D}$ in the population as a whole.

In conclusion, we identified seasonal variation in serum $25(\mathrm{OH}) \mathrm{D}$ in Hong Kong, peaking in early autumn (September) and troughing in early spring (March). Children aged 6-17 years, and girls and women had lower serum 25(OH)D levels than adults, boys and men. For children aged 6-17 years, more sunlight exposure and more intake of fish and eggs could improve vitamin D status.

\section{Supplementary material}

To view supplementary material for this article, please visit http://dx.doi.org/10.1017/S0007114515001683

\section{Acknowledgements}

This study was supported by the Research Fund for the Control of Infectious Diseases of the Health, Welfare and Food Bureau of the Hong Kong SAR Government (grant nos CHPCE-03 and 11100862), and the Area of Excellence Scheme of the Hong Kong University Grants Committee (grant no. AoE/M-12/06). The funding bodies had no role in study design, data collection and analysis, preparation of the manuscript, or the decision to publish.

D. K. M. I. has received research funding from F. HoffmannLa Roche Limited. J. S. M. P. receives research funding from Crucell NV. G. M. L. has received consulting honoraria from Janssen Pharmaceuticals. B. J. C. has received research funding from MedImmune, Inc. and Sanofi Pasteur, and consults for Crucell NV. The authors report no other potential conflicts of interest.

The authors' contribution are as follows: C. X. and B. J. C. contributed to the study conception and design. V. J. F., S. N., D. K. M. I., A. M.-S. K., G. M. L. and B. J. C. collected data. R. A. P. M. P. and J. S. M. P. conducted laboratory tests. C. X. and V. J. F. analysed data. C. X. wrote the first draft of the paper. All authors contributed to the interpretation of data and approved the final manuscript.

We thank Chan Kit Man, Calvin Cheng, Lai-Ming Ho, Ho Yuk Ling, Nicole Huang, Lam Yiu Pong, Lincoln Lau, Winnie Lim, Tom Lui, Tong Hok Leung, Loretta Mak, Eunice Shiu, Joey Sin, Jessica Wong, Kevin Yau and Eileen Yeung for research support. We thank Susan Chiu for helpful discussions.

\section{References}

1. Holick MF (2007) Vitamin D deficiency. $N$ Engl J Med 357, 266-281.

2. Giovannucci E, Liu Y, Rimm EB, et al. (2006) Prospective study of predictors of vitamin D status and cancer incidence and mortality in men. $J$ Natl Cancer Inst 98, 451-459.

3. Lappe JM, Travers-Gustafson D, Davies KM, et al. (2007) Vitamin D and calcium supplementation reduces cancer risk: results of a randomized trial. Am J Clin Nutr 85, 1586-1591.
4. Bergman P, Lindh AU, Bjorkhem-Bergman L, et al. (2013) Vitamin D and respiratory tract infections: a systematic review and meta-analysis of randomized controlled trials. PLOS ONE 8, e65835.

5. Ginde AA, Mansbach JM \& Camargo CA Jr (2009) Association between serum 25-hydroxyvitamin D level and upper respiratory tract infection in the Third National Health and Nutrition Examination Survey. Arch Intern Med 169, 384-390.

6. Douglas AS, Ali S \& Bakhshi SS (1998) Does vitamin D deficiency account for ethnic differences in tuberculosis seasonality in the UK? Ethn Health 3, 247-253.

7. Cannell JJ, Vieth R, Umhau JC, et al. (2006) Epidemic influenza and vitamin D. Epidemiol Infect 134, 1129-1140.

8. Wang TJ, Pencina MJ, Booth SL, et al. (2008) Vitamin D deficiency and risk of cardiovascular disease. Circulation 117, 503-511.

9. Wahl D, Cooper C, Ebeling P, et al. (2012) A global representation of vitamin D status in healthy populations. Arch Osteoporos $7,155-172$.

10. Hilger J, Friedel A, Herr R, et al. (2013) A systematic review of vitamin D status in populations worldwide. BrJ Nutr 111, $23-45$.

11. Chen TC, Chimeh F, Lu Z, et al. (2007) Factors that influence the cutaneous synthesis and dietary sources of vitamin $D$. Arch Biochem Biophys 460, 213-217.

12. Holick MF (2009) Vitamin D status: measurement, interpretation, and clinical application. Ann Epidemiol 19, 73-78.

13. Viljakainen HT, Palssa A, Kärkkäinen M, et al. (2006) A seasonal variation of calcitropic hormones, bone turnover and bone mineral density in early and mid-puberty girls - a cross-sectional study. Br J Nutr 96, 124-130.

14. Bhattoa H, Bettembuk P, Ganacharya S, et al. (2004) Prevalence and seasonal variation of hypovitaminosis $\mathrm{D}$ and its relationship to bone metabolism in community dwelling postmenopausal Hungarian women. Osteoporos Int 15, 447-451.

15. Cowling BJ, Ng S, Ma ES, et al. (2012) Protective efficacy against pandemic influenza of seasonal influenza vaccination in children in Hong Kong: a randomized controlled trial. Clin Infect Dis 55, 695-702.

16. Nucci AM, Russell CS, Luo R, et al. (2013) The effectiveness of a short food frequency questionnaire in determining vitamin D intake in children. Dermatoendocrinol 5, 205-210.

17. Bolek-Berquist J, Elliott ME, Gangnon RE, et al. (2009) Use of a questionnaire to assess vitamin D status in young adults. Public Health Nutr 12, 236-243.

18. Roth HJ, Schmidt-Gayk H, Weber H, et al. (2008) Accuracy and clinical implications of seven 25-hydroxyvitamin D methods compared with liquid chromatography-tandem mass spectrometry as a reference. Ann Clin Biochem $\mathbf{4 5}$, 153-159.

19. Ono Y, Suzuki A, Kotake M, et al. (2005) Seasonal changes of serum 25-hydroxyvitamin D and intact parathyroid hormone levels in a normal Japanese population. J Bone Miner Metab 23, $147-151$.

20. Hong Kong Observatory, The Government of the Hong Kong Special Administrative Region (2014) Daily Extract of Meteorological Observations. http://www.weather.gov.hk/ cis/dailyExtract_e.htm? $=2009 \& \mathrm{~m}=7$ (accessed March 2014).

21. Khoo AL, Koenen HJ, Chai LY, et al. (2010) Seasonal variation in vitamin $\mathrm{D}_{3}$ levels is paralleled by changes in the peripheral blood human $\mathrm{T}$ cell compartment. PLoS ONE 7, e29250.

22. Zittermann A, Scheld K \& Stehle P (1998) Seasonal variations in vitamin D status and calcium absorption do not influence 
bone turnover in young women. Eur J Clin Nutr 52, 501-506.

23. Carnevale V, Modoni S, Pileri M, et al. (2001) Longitudinal evaluation of vitamin D status in healthy subjects from southern Italy: seasonal and gender differences. Osteoporos Int 12, 1026-1030.

24. Ross AC, Manson JE, Abrams SA, et al. (2011) The 2011 report on dietary reference intakes for calcium and vitamin D from the Institute of Medicine: what clinicians need to know. J Clin Endocrinol Metab 96, 53-58.

25. Dawson-Hughes B, Mithal A, Bonjour J-P, et al. (2010) IOF position statement: vitamin $\mathrm{D}$ recommendations for older adults. Osteoporos Int 21, 1151-1154.

26. Nakamura K, Nashimoto M, Hori Y, et al. (1999) Serum 25-hydroxyvitamin D levels in active women of middle and advanced age in a rural community in Japan. Nutrition 15, $870-873$.

27. Nakamura K, Nashimoto M \& Yamamoto M (2001) Are the serum 25-hydroxyvitamin D concentrations in winter associated with forearm bone mineral density in healthy elderly Japanese women? Int J Vitam Nutr Res 71, 25-29.

28. Suzuki T, Kwon J, Kim H, et al. (2008) Low serum 25-hydroxyvitamin D levels associated with falls among Japanese community-dwelling elderly. $J$ Bone Miner Res 23, $1309-1317$

29. Ho-Pham L, Nguyen N, Lai T, et al. (2011) Vitamin D status and parathyroid hormone in a urban population in Vietnam. Osteoporos Int 22, 241-248.

30. Chailurkit LO, Kruavit A \& Rajatanavin R (2011) Vitamin D status and bone health in healthy Thai elderly women. Nutrition 27, 160-164.

31. Soontrapa S \& Chailurkit L (2005) Difference in serum calcidiol and parathyroid hormone levels between elderly urban vs suburban women. J Med Assoc Thai 88, S17-S20.

32. Tsai K, Hsu S, Cheng J, et al. (1997) Vitamin D stores of urban women in Taipei: effect on bone density and bone turnover, and seasonal variation. Bone 20, 371-374.

33. Kelishadi R, Moeini R, Poursafa P, et al. (2013) Independent association between air pollutants and vitamin D deficiency in young children in Isfahan, Iran. Paediatr Int Child Health 34, 50-55.

34. Powe CE, Evans MK, Wenger J, et al. (2013) Vitamin D-binding protein and vitamin D status of Black Americans and White Americans. $N$ Engl J Med 369, 1991-2000.

35. Davies PS, Bates CJ, Cole TJ, et al. (1999) Vitamin D: seasonal and regional differences in preschool children in Great Britain. Eur J Clin Nutr 53, 195-198.
36. Klenk J, Rapp K, Denkinger MD, et al. (2013) Seasonality of vitamin D status in older people in Southern Germany: implications for assessment. Age Ageing 42, 404-408.

37. Mavroeidi A, O'Neill F, Lee PA, et al. (2010) Seasonal 25hydroxyvitamin $\mathrm{D}$ changes in British postmenopausal women at $57^{\circ} \mathrm{N}$ and $51^{\circ} \mathrm{N}$ : a longitudinal study. J Steroid Biochem Mol Biol 121, 459-461.

38. Nakamura K, Nashimoto M \& Yamamoto M (2000) Summer/ winter differences in the serum 25-hydroxyvitamin $\mathrm{D}_{3}$ and parathyroid hormone levels of Japanese women. Int J Biometeorol 44, 186-189.

39. Vecino-Vecino C, Gratton M, Kremer R, et al. (2006) Seasonal variance in serum levels of vitamin $\mathrm{D}$ determines a compensatory response by parathyroid hormone: study in an ambulatory elderly population in Quebec. Gerontology 52, 33-39.

40. Kasahara AK, Singh RJ \& Noymer A (2013) Vitamin D (25OHD) serum seasonality in the United States. PLOS ONE 8, e65785.

41. MacDonald D \& Swaminathan R (1988) Seasonal variation in $25-\mathrm{OH}$ vitamin D in plasma of Hong Kong Chinese. Clin Chem 34, 2375.

42. Levis S, Gomez A, Jimenez C, et al. (2005) Vitamin D deficiency and seasonal variation in an adult South Florida population. J Clin Endocrinol Metab 90, 1557-1562.

43. Sherman SS, Hollis BW \& Tobin JD (1990) Vitamin D status and related parameters in a healthy population: the effects of age, sex, and season. J Clin Endocrinol Metab $\mathbf{7 1}$, 405-413

44. Robien K, Butler LM, Wang R, et al. (2013) Genetic and environmental predictors of serum 25-hydroxyvitamin D concentrations among middle-aged and elderly Chinese in Singapore. BrJ Nutr 109, 493-502.

45. Chailurkit LO, Aekplakorn W \& Ongphiphadhanakul B (2011) Regional variation and determinants of vitamin D status in sunshine-abundant Thailand. BMC Public Health 11, 853 .

46. Choi HS, Oh HJ, Choi H, et al. (2010) Vitamin D insufficiency in Korea - a greater threat to younger generation: the Korea National Health and Nutrition Examination Survey (KNHANES) 2008. J Clin Endocrinol Metab 96, 643-651.

47. Lamberg-Allardt C (2006) Vitamin D in foods and as supplements. Prog Biophys Mol Biol 92, 33-38.

48. Schmid A \& Walther B (2013) Natural vitamin D content in animal products. Adv Nutr 4, 453-462. 